\title{
Indonesian Authors in Geneeskundige Tijdschrift voor Nederlands Indie as Constructors of Medical Science
}

\section{WAHYU SURI YANI}

Alumny History Department, Universitas Gadjah Mada

Email: wahyu.suri.y@mail.ugm.ac.id or wahyusrikandi117@gmail.com

\begin{abstract}
Access to the publication Geneeskundig Tijdschrift voor Nederlandsch-Indië (GTNI), a Dutch Indies medical journal, was limited to European doctors. Although Stovia (School ter Opleiding van Inlandsche Artsen) was established to produce indigenous (Bumiputra) doctors, its students and graduates were not given access to GTNI. In response, educators at Stovia founded the Tijdschrift Voor Inlandsche Geneeskundigen (TVIG) as a special journal for indigenous doctors. Due to limited funds, TVIG the only scientific medical publication for indigenous doctors - ceased publication in 1922. The physicians formed Vereeniging van Inlandsche Geneeskundigen (VIG) an association for pribumi (native) doctors to express various demands for equal rights, one of which was the right to access GTNI. The protests and demands of the bumiputra doctors resulted not only in being granted reading access rights but also being able to become writers for GTNI. Bumiputra doctors who contributed to GTNI included Bahder Djohan and Johannes Leimena. However, they were not the only authors who contributed to GTNI during the Dutch East Indies era. After Indonesia became independent, both doctors played major roles in laying the foundation for Indonesia's health education system and implementing village-based health policies. This article is part of a research project on Indonesia's health history using the archives of the GTNI, TVIG and books written by doctors who contributed to GTNI which were published from the early twentieth century onwards. This paper reconstructs the role of GTNI writers in building Indonesian health knowledge.
\end{abstract}

\begin{abstract}
Abstrak
Dalam mengakses Geneeskundig Tijdschrift voor Nederlandsch-Indië (GTNI) sebagai sebuah jurnal kedokteran Hindia Belanda, secara eklusif terbatas hanya untuk golongan dokter Eropa. Walaupun Stovia (School ter Opleiding van Inlandsche Artsen) dibuka untuk melahirkan dokter-dokter dari bumiputra. Lulusan Stovia tetap tidak bisa mendapat hak akses membaca GTNI. Dilain sisi para pendidik di Stovia mendirikan Tijdschrift Voor Inlandsche Geneeskundigen (TVIG) sebagai jurnal khusus untuk para dokter bumiputra. Akibat keterbatasan dana, TVIG sebagai satusatunya media ilmiah dokter pribumi berhenti diterbitkan tahun 1922. Dokter bumi putra bersatu dibawah organisasi Vereeniging van Inlandsche Geneeskundigen (VIG) menyampaikan berbagai tuntutan kesetaraan hak untuk mereka sebagai dokter, salah
\end{abstract}

\section{Keywords:}

Bahder Djohan; Constructor; GTNI; Leimena; Stovia; Pribumi Doctors; TVIG

\section{Kata Kunci:}

Bahder

Djohan;

GTNI;

Leimena;

Pembangunan;

Stovia; TVIG 
satunya adalah hak akses GTNI. Protes dan tuntutan dokter bumiputra membuahkan hasil. Mereka tidak hanya mendapatkan hak akses baca tetapi juga menjadi penulis di GTNI. Dokter bumiputra yang berkontribusi di GTNI diantaranya adalah Bahder Djohan dan Johannes Leimena. Mereka tidak hanya sebagai penulis GTNI ketika zaman Hindia Belanda. Ketika Indonesia Merdeka mereka berperan utama dalam meletakkan dasar pendidikan kesehatan Indonesia dan menerapkan kebijakan kesehatan yang berbasis rakyat desa. Penelitan ini adalah bagian dari penelitian sejarah kesehatan Indonesia dengan menggunakan arsip GTNI, TVIG dan juga menggunakan buku-buku karangan para dokter yang berkontribusi di GTNI yang diterbitkan semenjak awal abad 20. Tulisan ini merekonstruksi bagaimana peran penulis GTNI membangun pengetahuan kesehatan Indonesia.

\section{Introduction}

The contribution of students of Stovia (School tot Opleiding van Indische Arts), the medical school for indigenous doctors in Batavia during the colonial period, in opposing colonialism and nation-building has been written about extensively. For example, Hans Pols (2019) in his book discusses how doctors formed a movement to address nation-building for the new state of Indonesia, not only in the fields of education and health, but also in politics. (Hans Pols, 2019). Hans discusses doctors movements from colonial times to the beginning of the revolution, while Vivek Neelakantan (2019) discusses the struggle of doctors after independence in addressing health problems during Indonesia's development as a young nation in the Soekarno era, and producing new doctors to respond to the shortage of health workers (Vivek Neelakantan, 2019). A recent research project, Dieka's thesis, examines how the daily lives of Stovian students reflect the modernization process of indigenous Indonesian society (Dieka Wahyudha Mardheni, 2017).

Meanwhile, Liesbeth Hesselink discusses indigenous authors or indigenous Indonesian writers who published their works in the colonial health journal Geneeskundige Tijdschrift voor Nederlands Indie (GTNI) (Liesbeth Hesselink, 2019). Hesselink discusses health education for bumiputra students in Stovia, and compiled indigenous doctors' writings in GTNI, including Indonesian-Chinese doctors. However, Hesselink only discusses indigenous doctors as writers in general nor discusses their work work after independence.

This article continues Liesbeth Hesselink's recent work by focusing on the main patterns and ideas of indigenous authors published by GTNI, and in another medical journal that was founded later, namely Tijdschrift Voor Inlandsche Geneeskundigen (TVIG). Publishing a paper in the GTNI journal was highly prestigious for Stovia students. However, the GTNI as a whole was dominated by European doctors. As a result, the process for publishing articles in GTNI was competitive and challenging for indigenous Stovian 
students who sought to overcome discrimination against indigenous doctors . The creation of TVIG provided another option for native Stovian students to publish medical articles but TVIG only survived for a brief period. This article examines the dynamics experienced by native Stovian students in the publication process for their articles in both GTNI and TVIG.

Apart from the publication process, the article also discusses the correlation between the writings of native Indonesian doctors in GTNI with their struggles in laying the foundation for Indonesia's newly established basis knowledge of Indonesia health . The article examines how the correlation between native Stovia students as contributors to GTNI with their role as activist of health in era proclamation of Indonesian independence 1945 to the 1950s. The data sources come from the genealogy of Stovia students' writings published in GTNI and elsewhere. To become a contributor to GTNI, an article was not only sent to the publisher but also sent as part of a report to the Dutch colonial government. By writing in GTNI, Stovia students showed that they were capable of meeting the standards set by the Netherlands, challenging discrimination from European doctors.

First, this article discusses indigenous doctors and their struggles to have their work published in GTNI and the social issues in their writing. Then, this article discusses the polemic of TVIG as an indigenous doctor's journal which was originally contributed to by ghost writers. Furthermore, the article turns to consider the socio-political trajectories of Stovia students who were writers at GTNI and TVIG during the Indonesian independence era.

\section{GTNI in the Dutch East Indies}

GTNI was first published in 1852 by Willem Bosch, the Head of the Netherlands Indies Medical Service, as the official medical journal of the Dutch East Indies Ministry of Health. The journal, which ran for 90 years, published 4500 articles. The articles in this journal on various epidemics in the Dutch East Indies in the 19th century, focused on how diseases were infected people. The initial plan was to publish a journal with 150 subscribers with a subscription cost of f12 per year. GTNI subscribers were not only doctors but also veterinarians, civil servants (heads of ministries); administrators such as Residents (heads of government in a residency), and institutions (even the Ministry of Colonies). Initially, the editors planned to publish one volume annually, because initally there were few article submissions and reports sent in by doctors, however by 1884 this had changed (Liesbeth Hesselink, Jan Peter Verhave, Leo van Bergen, 2019). The journal later began to be published every two weeks starting in 1928 and since 1932, GTNI accepted advertisements including on its front page. GTNI not only functioned as a medical publication but also as a health report for the Dutch East Indies 
government, especially regarding the health of the military during colonial wars such as Dutch soldiers fighting in Aceh, especially when the beri-beri outbreak broke out among soldiers. The existence of GTNI supported the Dutch government in carrying out its policies, especially in dealing with tropical diseases.

To entrench its political power, the Dutch colonial government had encouraged several efforts to better understand the natural conditions in the archipelago. The goal was, of course, to ensure the continuity of power and minimize the potential threats that existed (Gani Jaelani, V.2 no. 2, 2019: 32-49). Researching disease was one way to ensure that the continuation of power, especially if the disease threatened the plan to control an area, as in the case of beri-beri which affected thousands of Dutch soldiers in Aceh. As a result, the Netherlands was not only embattle the people of Aceh whic is resistence from beri-beri but also combat beri-beri as the another enemy.

The spread of beri-beri in Aceh prompted the Dutch government to issue and enact special policies, one of which was to establish a research laboratory. This first laboratory was called the Laboratorium Voor Pathologische Antomie En Bacteriologie (Laboratory for Pathological Anatomy and Bacteriology) which was led by Eijkman. The establishment of this laboratory also affected the quality of the content of GTNI. Articlesin GTNI from 1852 to 1888 did not contain in-depth laboratory research and its articles were in the form of military health reports on conditions on the battlefield, the sporadic spread of the plague, as well as statistics on the diseases in Dutch government plantations and mines that afflicted the coolies. Eijkman's research work in the laboratory onberi-beri and other tropical diseases was subsequently published in GTNI..

Eijkman's research work influenced the new direction of GTNI as a medium for medical research in the Dutch East Indies. His efforts in preventing disease through various observations and experiments in the laboratory opened up new lines of research in efforts to prevent disease that were more rational and systematic. Before laboratories existed, disease management was only sporadic. Laboratory methods using controlled conditions and able to be reproduced in identifying diseases. The existence of a laboratory in the Dutch East Indies had an important role in the improving the health of the Dutch Indies by controlling tropical diseases. Eijkman's method of researching diseases in the laboratory and solving the problem of beri-beri influenced the development of GTNI as a medical journal and becoming a reference for various countries. This success also encouraged the establishment of various other research laboratories in the Dutch East Indies such as the Bandung Pasteur Institute, and similar facilities in in Medan, Malang, Surabaya, Makassar and various other cities totaling approximately 140 institutes (P. Hornig \& F. Verdoorn, 1945). The research, which was 
carried out in various emerging laboratories, shaped the development of GTNI.

The main requirement to become a contributor to GTNI was being a doctor. Creating a medical profession in the Dutch East Indies began with the establishment of the Javanese medical school in 1853, a year after the publication of the first edition of GTNI in 1852. The Javanese Doctors School, the forerunner of STOVIA, was a major milestone in the training of doctors and later became an important source of contributors to GTNI. The success of being published in GTNI was inseparable from theeducation gained at STOVIA, which continued to improve its educational curriculum, and championing bumiputra physicians in gaining the samerights as European doctors, which included the battle to gain access to read GTNI and become an author for this prestigious journal.

Bumiputra doctors' involvement in GTNI, according to Liesbeth, began in 1904 with Lim Tjat Fa (Liesbeth Hasselink, 2019). Lim Tjat Fa was born in Muntok, on Bangka Island in 1891 to an ethnic Chinese family. His father, a deputy chairman of the Nederlandsche Stoomvaartmaatschappij (the forerunner of Paketvaart), gave him the opportunity to enjoy a standard European education. At 10 years old, he went to the Netherlands and after finishing high school in 1891 Lim continued his studies at Leiden University in Medicine. ${ }^{1}$ However, his success in being published in the GTNI journal did not start with STOVIA, because he hadbeen educated in the Netherlands and graduated from Leiden University as a doctor.

At first it seemed that to be published in GTNI was impossible for bumiputra doctors. The primary obstacle was the commonly held belief that native doctors were under capacity as a doctor. This prejudice meant a low regard for the professional qualifications of the indigenous doctor. Various attempts were made by bumiputra doctors such as, bdul Rivai to demand that the rights of native doctors be recognized as the same as European doctors. Action to achieve bumiputra doctors' rights became increasingly organized and united under the umbrella of the Vereeniging van Inlandsche Geneeskundingen (VIG), an association of indigenous doctors which was formed after a critical speech by Doctor Tehupeiory who protested against discrimination faced by native doctors and their lack of equal rights. The demands of bumiputra doctors were the right to be treated as a fellow professional, both in terms of salaryand the right to access the GTNI.

\section{TVIG as a Health Scientific Journal for Bumiputra Doctors}

Stovia was founded as an educational institution to produce Bumiputra doctors

1) Feuilleton. In Memoriam Dr. Lim Njat Fa En Zijn Verdienste Voor De Ontwikkeling Van Het Ziekenhuis- En Verpleegwezen Op Java Dalam N.T.V.G 72.I.II. 1346 Sabtu 17 Maret 1928. 
to treat patients in the Dutch Indies. These doctors not only treated the physically sick, but also worked to heal and awaken the souls of the Indonesian people who suffering as a consequence of colonialism (Hans Pols, 2019). The spirit of national awakening sparked by the activities of the Stovian students was inseparable from how Stovian students lived in their dormitories. Returning from studying various medical sciences at school, the dormitory was a place for rest and creativity, especially as these spaces united students from various backgrounds and ethnicities. Dormitories were a place to share, interact, organize and cause conflict, which included hazing rituals (Dieka, 2017: 99). In these dormitories, students shared with each other the fate of their regions, which became an inspiration to form regional associations such as Jong Java, Jong Sumatranen Bond and others.

The location of Stovia in Batavia, the center of the Dutch East Indies government, also provided wide access to various multicultural elements of society, and brought Stovian students in contact with many elites. Batavia was the center of political, economic and cultural activities and a gateway to contact with the outside world. It was a place where intellectuals gathered, interacted with each other and exchanged ideas, which in turn accelerated intellectual thought. Batavia was also the residence of a group of non-native intellectuals who influenced how Stovian students thought and enriched their ideas. This cultural acculturation among Stovian students with a variety of people made the candidate Bumiputra doctors modern, open-minded people who also cultivated ideas and an enthusiasm for their work. Batavia also was a center for information, whose residents there, mass media which provided newspapers and magazines from local,national and international publishers.

Students at Stovia were not only avid consumers of mass media, but also had access to other publications, such as Locomotive and Expression (M.A Hanafiah: 10 Years in Stovia's Dormitory: 107). It is no wonder the doctors were also journalists who pubished articles in various newspapers. This included Tirto Adhi Soerjo who founded Medan Prijaji and Abdul Rivai, the first Indonesian to publish a Malay-language newspaper in Europe, namely Pewarta Wolanda on 14 July 1900, in Amsterdam. Returning from studying, Rivai later published Bandera Wolanda and Bintang Hindia. Although Abdoel Moeis did not succeed in completing his education at Stovia, he worked not only as a member of the Volksraad but also as a novelist: the novel Salah Asuhan (Never the Twain) (1928), which became one of his phenomenal and bestselling works tells the story of his love in Stovia. Other novels such as Pertemuan Jodoh (Meeting of Soulmates) () (1933), Surapati (1950), and Robert: Anak Surapati (Robert, Surapati's Child) (1953). Access to the mass media such as newspapers also provided opportunities for Stovia students, notably Bahder Djohan (discussed further below), to have their writing published. . As well as increasing students' income, these articles also contributed ideas to the nation. 
Regional backgrounds also influenced the work of Stovian students' birth as writers such as the Stovian Minangkabau students who came from Sumatra's west coast. . Since 1859, on the west coast of Sumatra various mass media organizations had begun to develop, publishing in Arabic, Malay, and Dutch. This also influenced the emergence of a style of writing by Minangkabau doctors. Indeed there was a high level of interest from young Minangkabau men in studying at Stovia. From 1900-1914, 18\% of Stovian students were Minangkabau. In 1914, more than 25\% of the intake were Minangkabau were accepted into Stovia. In 1942 Koto Gadang, one of the villages in Minangkabau, located in Agam, had produced forty Stovia graduates (Elizabeth E. Graves, 1981). The large number of Stovia graduates from the Minangkabau ethnic area can also be seen from their considerable involvement as contributors to GTNI and contribution to developing Indonesia's basic health needs since the beginning of Indonesia's independence.

A significant event which influenced these students as health science researchers, and their journey writer for GTNI, was the establishment of Tijdschrift Voor Inlandsche Geneeskundigen (TVIG). TVIG was a medical journal that was founded for male physicians in 1893, both for students and graduates who served in various regions. When TVIG was founded, the leader of Stovia was Christian Eijkman who also served as the leader of the Pathology Laboratory. Eijkman believed that bumiputra doctors were there to meet the needs of Europeans doctor to know secret indogenieus medicine. Within this view, the implementation of their medical education must be considered so that they understood the field. Eijkman noticed that there were no medical magazine specifically for bumiputra doctors. This situation led Stovia to establish TVIG which was published once every two months (De Waart, 1995).

C.L. Van Der Burg was involved in the birth of TVIG in 1893. Van Der Burg announced that the existence of a medical journal for bumiputra doctors in Dutch was intended to maintain the quality of indigenous doctors. Van Den Burg explained that contributing to this first magazine were current and former schoolteachers, Inspector Vorderman and students with the highest grades under the guidance of their teachers. Van der Burg hoped that bumiputra doctors could work well together for the development of TVIG. In the first issue of TVIG, several students submitted draft articles including Renong, Kasroeno, Si-Moro and Dawoea. ${ }^{2}$

Renong, whose real name was Raden Renong was born in Poerbalinggo in 1871 and entered Stovia on 14 August 1886 and completed his studies on 19 March 1892. Kasroeno was born in Koeripan in 1870 and entered Stovia

2) C.L.Van Der Burg. Tijdschrift Voor Inlandsche Geneeskundigen. Eerste Jaargang. Batavia, Landsdrukkerij 1893. 
on 13 September 1983 and finished his studies in Stovia on 08 March 1891. They became contributors to TVIG after they had completed their studies and were working as doctors. Van der Burg hoped that this development would lead to an increase in the contributions from indigenous doctors to TVIG. Indigenous doctors such as Javanese doctors, unlike the Dutch, were able to closely observe indigenous people's habits from their ethnic group. As a consequence, indigenous doctors were in a position to discover more about the health system and diseases in their respective ethnic areas. Van Der Burg insisted that this magazine was not commercial but part of the scientific spirit in appreciating the rich East Indies, and in doing so prove useful to its readers.

Thethemes addressed in TVIG were very diverse, such as on iodoform disease, clysmata, trachoma difformans, massage, foreign objects in the nose, opium shifters, and ichthyol. The articles were not limited to just health matters. TVIG also published stories of the first days of life in Stovia, the history of medical education, and personal details about the articles' authors. In the first year of the publication of the journal TVIG, there were several essays which were essential for gaining medical knowledge including rice wine, some original recipes against skin diseases, custom from thei village, poison, and about massage in the Padang Highlands (Padangsche Bovenlanden). But, the existence of TVIG, not only provided training for native doctors by enhancing their knowledge as doctors however, more importantly, the information provided was very beneficial for the Dutch government because it was difficult for Dutch doctors to access this knowledge that was directly related to indigenous civil life.

During the first decades of the 20th century, the topic of X-rays, diet, beri-beri, various epidemics, and new theories about malaria received a lot of attention in this journal (Hans Pols, 2019). In 1903, this journal published its 12 th edition. However, the Dutch government had not approved the rules regarding financing for the journal (Djoko Marihandono, 1994). In the Stovia annual report in 1903, the editorial staff reported that TVIG contained many useful articles. Financial support for publishing TVIG would be very useful for the development of TVIG, but TVIG funding was only granted in 1904. Based on the Government Decree dated January 14, 1904 number 29, a fund of f1750 was provided for the publication of a bumiputera medical magazine, and if possible, more copies would be printed than the previous year. (Djoko Marihandono, 1906: 67).

In TVIG the 1910s there were articles about hookworm, tuberculosis, syphilis, dysentery, the use of microscopes, and the role of rats in spreading the bubonic plague. In 1915, C.D. de Langen, STOVIA's internal medicines instructor, promised to increase the number of articles submitted by Dutch East Indies doctors. ${ }^{3}$ In the early 1920s, the editorial board of the journal

3) C.D. De Langen. “Aan De Lezers!,” Tijdschrift Voor Inlandsche Geneeskundigen 23, 
consisted almost entirely of Dutch Indies doctors and TVIG was soon seen as a partner of the GTNI journal, as the leading journal of the entire Dutch East Indies colony. ${ }^{4}$ TVIG served to share knowledge between Stovia alumni, teachers, and students. Especially since 1851, Stovia produced many alumni who went on to hold positions in various regions. It was the TVIG journal which connected them and became a way of curating the knowledge they had gained and adding new information related to the world of health.

While TVIG was for native doctors, on the other hand, the doctors were also used as intermediaries by Dutch doctors to find out more about indigenous medicine. For instance, an editor and teacher at the school, A. Van Der Scheer (1893: 56), asked them to collect data on the use of opium. Likewise, A.G. Vorderman, a Civil Medical Services Inspector, was very interested in traditional Indonesian medicine and a collaborative article was published in GTNI. In obtaining his written data, Vorderman asked a Javanese doctor to find out the tricks used by native criminals when preparing poison to get rid of people without suspicion. In response to Vorderman's request, the Javanese doctors provided an abundance of data which he compiled into a special book. Another case research by Vorderman was the beri-beri epidemic which hit the Dutch East Indies not only in the war in Aceh but also in prisons in Java and Madura. Vorderman asked Javanese doctors for help to collect rice samples used by indigenous people. This was to determine the ratio of thiamin in rice used by rural communities to rice provided by the government for soldiers, plantation and mining workers and prisoners in prisons. The rice that the Stovia students collected from the community was mashed rice that was still brown and different from what the government used, which was finely ground rice. This contribution helped to determine that beri-beri is caused by a deficiency of thiamine which had been lost in the process of milling rice. The reason why rural people were not exposed to beri-beri was that the mashed rice that they consumed still had a brown silver skin, silver skin or brown color that is, indicating thiamine or vitamin B1.

Some contributions to the journal even concerned menstruation, abortion and circumcision. A. van der Scheer asked his students, "will they try to "learn about abortion from traditional healers, because in European medicine no one has been able to find an abortion that works in all cases". This quote reflects an equal relationship between European medicine and the native medicinal system. European medicine did not know about safe abortion, but women and traditional healers who are often underestimated practiced abortion well, stated A. van der Scheer (1893). Based on from STOVIA student, western medical practices could learn from traditional

No 1, 1915, pp. 1-4.

4) R. Seno, "Ons Tijdschrift," Tijdschrift Voor Inlandsche Geneeskundigen 27, Mo 2 (1919), pp. 1-6. 
healers in their practice of abortion.

The case above explains how indigenous doctors had great potential for the development of tropical medicine, and that this was exploited by Dutch doctors who used them as sources or agents to seek information about indigenous medicine for local people. The process was carried out for the reason of learning and was a practicum for prospective doctors. However, student doctors were kept from treating the community until gaining further knowledge and skills.. Yet in fact, bumiputra doctors were used as shadow or ghost writers to fulfil the research needs of teachers in Stovia. But TVIG did not last long. This journal, which supported indigenous doctors as a medium for sharing health knowledge, ceased publication in 1922. TVIG died at Stovia due to a lack of funds. This event led bumiputra doctors try to gain access to GTNI to develop their ideas and health knowledge.

Although TVIG ceased in 1923, de Langen encouraged STOVIA senior students to form medical discussion groups where they presented and discussed their research (Hans Pols, 2019). He also kept his library and collection of medical journals open to students. ${ }^{5}$ This access to this material was a way for students to be published in GTNI, gaining in research skills and recording the health conditions in the community and the patients they treated in hospitals.

Apart from TVIG, bumiputra doctors also has their own magazine, entitled Orgaan der Vereeniging van Inlandsche Geneeskundigen. This publication was first printed in 1914 under the bumiputra doctors' association or VIG. Orgaan had the same focus as TVIG, which was about medical professional issues, current news, voicing rights, as well as criticizing and providing input to the government. Orgaan was the only mass media outlet providing social support for the benefit of indigenous doctors (Hans Pols, 2019: 182). But in 1925, Orgaan was renamed Bulletin at the suggestion of Mohammad Amir, which had become a scientific journal because TVIG was closed in 1922. This scientific journal served as a medium to support Indies doctors in conducting medical research. The existence of the Bulletin, would support the scientific achievements of Indies doctors to a higher level, and in turn their social position would also improve. This publication, Bulletin, was an exclusive publication for native doctors who had received medical degrees in the Netherlands and medical doctoral degrees, a group which totaled no more than 30 people and gave birth to a new elite of the Indonesian medical profession (Hans Pols, 2019: 184-185). They also allowed advertisements for pharmaceuticals and medical equipment to appear in the journal. As a source of revenue, which also recognized there standing in the medical sphere.

5) F.L. Tobing, "Medisch Dispuut Gezelschap" Dalam STOVIA Almanak 1925 (Weltevreden: Kolff, 1925), p. 136-137 


\section{GTNI and TVIG Become the Forming Media for the Development of National Health Sciences}

To become a contributor to GTNI, indigenous doctors had to attain a high standard of skill and knowledge.. Bumiputra doctors who published in GTNI on average did not only take medical education at STOVIA but also continued onto higher education at the University of Amsterdam, the Netherlands, such as Sardjito, and Achmad Mochtar. They had a good command of the Dutch language, not only in speaking but also in putting ideas into writing. They not only worked as doctors in hospitals but also conducted research in the laboratory.

Liesbeth Hesselink describes in detail the six most productive individuals, who wrote between eleven to twenty nine papers. Among them is Raden Mas Sardjito, who published twenty nine articles, Carel Reinier Nicolaas Frederik van Joost published twenty six articles mainly related to tuberculosis, Achmad Mochtar published twenty five articles mainly related to leptospirosis (Weil's disease) and leprosy, Raden Soesilo's published twenty three articles main subject was malaria, Mohammad Amir wrote twenty-two articles especially on psychiatry and forensic medicine, and Mas Soetopo Reksapoetro published eleven articles, especially on leprosy (Liasbeth Hasselink, 2019). These doctors had all continued their education in the Netherlands and received medical degrees except for Mas Soetopo.

Likewise, Hans Pols discusses five doctors who were productively writing for GTNI and also agitated for Indonesia's independence.. Hans Pols examines three other names, besides Dr Sardjito and Achmad Muchtar, such as Sarwono Prawirohardjo, who published articles on pregnancy and childbirth and became the first chair of the Science Institute of Indonesia (Lembaga Ilmu Pengetahuan Indonesia - LIPI) after Indonesia's independence. Sutomo Tjokronegoro published articles on forensic medicine, cancer, ulcers and tuberculosis. In 1942, he became editor of the journal GTNI and the first Professor of Pathology at Universitas Indonesia (UI). And, finally, Raden Djenal Asikin Widjaja Koesoema wrote about various methods of analyzing blood samples and their uses (Hans Pols, National Geographic: 21 November 2017).

In contrast to Hans Pols and Liesbeth Hasselink, this article discusses two significant individuals and their work in building the newly independent Indonesia, especially in developing health science facilities, not only in educational institutions but also in terms of policies to develop the state and nation of Indonesia. These individuals are Bahder Djohan and Johannes Leimena. Despite not studying in the Netherlands, both were able to pass European standards as doctors. They were also active in working towards independence for the Indonesian people. Leimena was a representative for senior doctors from eastern Indonesia, and continued the spirit and struggle 
of his predecessor Tehupeiori. Bahder Djohan represented his fellow doctors from Sumatra, especially from the Minangkabau ethnic group, such as Abdul Rivai and Achmad Mochtar. The struggles of his predecessors inspired Bahder Djohan to fight for an independent Indonesia.

\section{Bahder Djohan}

Bahder Djohan was born on 30 July 301902 in Padang, West Sumatra (Sumatra's west coast). His father, Moh Rapal St. Burhanuddin came from Koto Gadang, Agam. While his mother, Lisah, came from Padang. Moh Rapal had a position as a prosecutor which was a very respected position at that time (Mardanas Safwan, 1985). Bahder Djohan finished his schooling in Hollandsch Inlandsche School (HIS) Bukittinggi and then continued his education at the Meer Uitgebreid Lager Onderwijs (MULO) school in Padang. While studying in Padang, Bahder Djohan began to become interested in the youth movement. In 1919, Bahder Djohan continued his studies at STOVIA in Jakarta, and graduated as a doctor in 1927.

Bahder Djohan's school was active in the youth organization Jong Sumatranen Bond. On 30 April 1926, a large crowd of youth gathered in Jakarta, which became known as the first Youth Congress and was attended by representatives of youth organizations such as Jong Java, Jong Sumatranen Bond, Jong Ambon, Sekar Rukun, Jong Islamieten Bond, Stedeerende Minahasaers, Jong Bataks Bond, and Youth of Theosophy. This congress was chaired by Mohammad Tabrani and Bahder Djohan as vice-chairman. During this historic congress, Bahder Djohan delivered a speech entitled "De Positie Van De Vrouw in De Indonesiche Samneving” (Position of Women in Indonesian Society) (Bahder Djohan, 1980).

Bahder Djohan began writing when he was a student in Stovia in 1913 sending his poetry and articles to newspapers (Bahder Djohan, 1980). At that time, sending articles to various newspapers was beneficial, because apart from getting payment, he was also able contribute ideas, criticize the government and publicize his thoughts.. After completing his studies in Stovia in 1927, Bahder Djohan worked at the Central Civic Hospital (Centrale Burgerlijke Ziekeninrichting - CBZ) now Dr. Cipto Mangunkusumo Hospital (Rumah Sakit Dr Cipto Mangunkusumo - RSCM) () with Professor De Langen in the internal medicine ward. Due to the integration of the internal medicine ward with pediatric diseases, Bahder Djohan's attention was very much focused on children's diseases (Kinderzieken). In his practice at this time most of the diseases found were beri-beri and gastroenteritis.

Beri-beri is found in babies because they are breastfed by mothers who suffer from vitamin B1 deficiency (Bahder Djohan, 1980). This disease, which had long been researched, came to prominence during the war in Aceh. After a series of studies, Eijkman and his friends found a cure (Laodin, 2005: 41- 
86). The issue of beri-beri was first published in 1853 and became a hot topic that has dominated since 1880, published in GTNI and has continued to be a topic that got much attention in GTNI. Bahder Djohan's write article about it and explained that beri-beri baby cannot be separated from being associated with those who consumed white rice without its brown epidermis. Based on Bahder Djohan's skills, he was entrusted by Prof. De Langen to teach Dutch doctors who had just graduated from the universities of Amsterdam and Leiden about tropical diseases. This honour made Bahder Djohan hated by other Dutch colleagues because he was a native.

To organize activitast pribumi doctor the VIG (Vereeniging van Inlandsche Geneeskundigen) was formed. With this organization, Indonesian doctors began to gain strength and self-respect. VIG was an organization that enabled native doctors unite and fight for their rights. In VIG, Bahder Djohan served as its secretary for 10 years (1929-1939). Bahder Djohan also supported his profession as a doctor with his work on the TVIG daily, not only as an editor but also by distributing it to Indonesian doctors who were scattered in various regions.

Bahder Djohan struggled for many things while at VIG, one of which was the low salaries of doctors and GTNI access rights. Indigenous doctors could subscribe to this magazine but only as specialists. This rule was later opposed by the native doctors, as they threatened to simultaneously withdraw from the bonds of doctor East indies if this regulation was not repealed. The limitation of GTNI access rights made it difficult for native doctors to gain knowledge. Moreover, the salaries of native doctors were much lower than European doctors and this made it difficult for them to subscribe to newspapers.

Bahder Djohan and his colleagues at VIG protested and threatened that if access to GTNI was not provided to all doctors, they would cut from their ties to medical magazines. This protest also received support from Professor de Langen as their teacher in Stovia who also urged the GTNI regulations to be changed (Mardanas Safwan, 1985). Due to this threat and Bahder Djohan's persistence as secretary of the medical association, this discriminatory regulation was abolished by the Dutch East Indies Government (Thalib Ibrahim, 1975: 72). De Langen's support for the struggle of his students was also a contributing factor to the success in the lifting of the GTNI access regulations. From this time onwards, native doctors did not only receive access to subscriptions but also started working as contributors to GTNI. The decision to open GTNI, changed the deployment rules GTNI was limited to certain circles, especially for Dutch doctor The scarcity of bumiputra doctors contributing to GTNI before 1939 in each edition (Liesbeth Hasselink, 2019) was also influenced by the limitation of the number of subscriptions to GTNI from bumiputra doctors. 
Bahder Djohan's writings for the GTNI, published in 1935 was coauthored with Professor De Langen. De Langen was Bahder Djohan's teacher in STOVIA and at the time of writing Bahder Djohan was working at the main hospital in Batavia as an assistant to Professor De Langen. Bahder Djohan's writing in GTNI describes Pellagra disease. De Langen discussed the ubiquitous presence of pellagra, while Bahder Djohan reviewed a pellagra case he faced in the hospital. This disease was diagnosed as being related to diet or poor nutrition. Today, it is known as being caused by being deficient in Vitamin B3. But the cases managed by Bahder Djohan of a Pellagra patients, were not only affected by his skin but also psychologically and mentally,many of whom died in the Mental Hospital. ${ }^{6}$

Bahder Djohan's medical experience, gained during the colonial period, was utilized and further developed after independence. When Indonesia was proclaimed it triggered Bahder Djohan to fight and become a member of the youth movement for an independent Indonesia. During a low point inthe revolutionary struggle in July 1947, when the Dutch launched its First Military aggression, and succeeded in occupying the PMI (Palang Merah Indonesia) office. Bahder Djohan saved PMI by moving to it to the RSUP (Rumah Sakit Umum Pusat) (Thalib Ibrahim, 1975: 72). Bahder Djohan realizeds that these two institutions he led were the important institutions for Indonesia which was fighting for its independence.

During the second Dutch military aggression, on 19 December 1948, before RSUP was occupied by Bahder Djohan as the leader, he moved medical equipment, medicines, office equipment and patients to his house. At that time, Bahder Djohan's house had functioned as the Indonesian Medical College or Sekolah Tinggi Kedokteran Indonesia (STKI). Bahder Djohan initiated the establishment of the STKI during the first Dutch military aggression attack in 1947 and at that time the Dutch established Universitas van Indonesia (Nugroho Notosusanto, 1977: 275). The university, which was founded by the Dutch, which was founded before Indonesia was occupied by Japan in 1942. Meanwhile, to unite doctors and nurses to help the people and soldiers who were fighting against Dutch military aggression, Bahder Djohan created an association called Bhakti Mulia (Thalib Ibrahim, 1975: 74). Bhakti Mulia was a new form of VIG which was managed by Bahder Djohan during the Dutch East Indies era.

Bahder Djohan was a doctor who laid the foundations for health education in the newly established Indonesia. Bahder Djohan's work ineducation led him to become the Minister of Education, Teaching and Culture (Menteri Pendidikan, Pengajaran dan Kebudayaan - PPK). In 1950 in the Natsir Cabinet, Bahder Djohan was appointed minister of PPK, and then

6) C. D. De Langen En Bahder Djohan: Pellagra In Nederlandsch-Indië. GTNI, DEEL 75, Afl. 8, 16 April 1935, pp. 659-662. 
in 1952 in the Wilopo Cabinet was reappointed as minister of PPK. In 19531954, he was appointed director of RSUP Cipto Mangunkusumo in Jakarta then from 1954-1958, he served as rector of the University of Indonesia (UI) in Jakarta. In 1958, Bahder Djohan entered retirement. During this period, Bahder Djohan was active in leading the Ibnu Khaldun University in Jakarta. He was also active in leading the Minangkabau Cultural Foundation in Jakarta to promote national culture.

Bahder's sought to combine health and education so as to allow Indonesia to develop rapidly. Bahder Djohan was a doctor who was entrusted to serve as the PPK minister in two cabinets, given the responsibility todo what was needed in response to the urgent needs for Indonesian health workers and also train new doctors. As a result, the education of doctors was given priority. To produce good doctors, Bahder Djohan paid attention to the quality of higher education. To improve the quality of higher education, Bahder Djohan sent teaching staff abroad to learn from various countries about health studies on a large scale (M. Natsir, 1980).

Bahder Djohan also turned his attention to the limitations of universities that provide medical faculties, especially for opening medical faculties outside Java. Some efforts to establish new medical faculties outside Java were successful and some failed. One of them was the medical school in Bukittinggi, the hometown of Bahder Djohan but unsucced to present. To realize the establishment of a medical school in Bukittinggi, the Indonesian government collaborated with the Australian government under the Colombo Plan. Cooperation with Australia was suspected by the central government as a form of foreign intervention (Vivek Neelakanatan, 2019: 224-225) as a form domestic insurrection. This period coincided with political tensions over criticism of the Revolutionary Government of the Republic of Indonesia (Pemerintah Revolusioner Republik Indonesia - PRRI) in West Sumatra against the inequalities of the central government.

The central government policy to eradicate PRRI by bombing the city of Padang and areas of West Sumatra was opposed by Bahder Djohan who met with military officials urging them to rethink the decision. Because his appeal was not accepted,Bahder Djohan, then threatened to resign as chancellor of the University of Indonesia. Bahder Djohan's position on military action caused ripples in the center of government. Bahder Djohan, who held an important portfolio in government, was accused of being pro-PRRI. His views on the attacks on the PRRI were met with threats of arrest and death from various parties. But his friend Johannes Leimena as the Minister of Health provided testimony on the character of Bahder Djohan as his comrade in Stovia (Darsyaf Rahman, 1980: 398-399), and his co-worker in the cabinet during the Soekarno era. Likewise, Bahder Djohan's life's work in putting Indonesia's health education system in place strongly supported Leimena's 
programs as Minister of Health.

\section{Johannes Leimena}

Johannes Leimena was born in Ambon on 6 March 1905. He graduated from Stovia in 1930, then continued his studies at Geneeskundige Hoogeschool Batavia and graduated in 1939. As a graduate of Stovia from Ambon, Leimena certainly learned from his predecessor who fought for the rights ofdoctors, such as Tehupeiori. Leimena was also active in the Maluku Youth Association. While studying at Geneeskundige Hogeschool, Leimena worked at the Centrale Burgelijke Ziekenrichting (CBG). During the Japanese Occupation, Leimena worked actively as director of Badjoe Asih, Purwakarta Hospital, West Java.

Leimena was born and received education in the early 20th century in STOVIA. In the early $20^{\text {th }}$ century awareness grew of the discriminatory of colonialism stirring nationalist feelings for independence.. When Leimena became part of the Youth Pledge participants, this sentiment began to flourish: it was the pinnacle of the awakening of awareness. This experience flows in his writings not only as a doctor but also about his Christianity and youth's role in serving the nation.

During the independence period, Leimena applied what he had written during the Dutch colonial era and implemented it when he was trusted by the Indonesian people to become Minister of Health over several periods. Leimena acted consistently with his religious beliefs as a Christian despite working in Muslim majority society. The Bandung Plan was one of Leimena's key achievements in building Indonesia's health system in the early decades of independence. This plan was inspired by his experiences when working in Bandung where he observed that the Sundanese were hesitant to use the facilities due to a perception there would be pressure to change religions. To dispel this perception, Leimena established a polyclinic referral system under medical personnel and nurses in villages around Bandung to coordinate preventive and curative health measures (Vivek Neelakantan, 2019: 99100). He distinguished his national policy from the colonial government by emphasizing that the Indonesian government was trying to expand health care to villages and he was trying to build a health organization, which was dependent on rural health (Vivek Neelakantan, 2019). This plan he explained during the World Health Organization (WHO) Congress in Geneva, "seventy per cent of the population in Indonesia live in rural areas, villages must receive health care attention" (Johannes Leimena, 1953: 7). Leimena's thinking was pro- lower class and pro-village.

Judging from Leimena's earliest writings when he wrote at school in Stovia until the end of his correspondence, Leimena was interested in writing about religion, church, the role of youth and health. His first contribution about religion and the church, was published in 1947. From this he went 
onto publish nineteen works, consisting of books and articles with the last published in 1975 about the power of faith in the context of the anniversary of the Jakarta theological high school. Related to youth, Leimena first wrote in 1934 under the title De Ontwikkeling van de CSV (Christen Studenten Vereniging) op Java. This article was published in the monthly magazine Nederlandsche Christen Studenten Vereniging and was related to the development of Christian student associations in Java. His second essay on youth was "Indrukken van de Madras Conferentie 1938, in the Algemene Protestantsche Kerkblad published in 1939 (Victer Silean, 2007: 285-291). Leimena's other writings related to politics and statehood included two writings before independence. In 1936 Leimena wrote on "Nationalistische Stromingen in Nederlandsch Indie", Elthote, 1935-1936, and in 1940 on "Hoe Beinvloeden de Wereldgebeurtenissen Ons Leven Hier en Wat Hebben Zij Ons te Zeggen”. (Victer Silean, 2007: 285-291).

Leimena's writings on health comprise nine papers in the GTNI, published from 1934-1941. In 1939, there was one paper at the cancer congress in Bandung, and one more final assignment at GH (Geneskundige Hogeschool) for his dissertation in 1939. Leimena's writings in GTNI in 1934 included two about "Cixitis Syphilitica and" Trombearteritis Obliterms" (Ziekte van Winiwater Burger). In 1935 he wrote on "Tubes Dorsalis" and "Takatracoloid Reactie", 1936 on "Primer Levercarcinoom”, 1937 on "Een Geval van PseudoPancreas-Cystena Trauma”. In 1939 on "Levertumoren en Takata Ara Reactie, at the Bandung cancer congress, his doctoral dissertation on Leverfunctie-Proeven bij Inheemschen" and his writing in the 1939 GTNI was about "Enkele resultaten van Het Klinisch Onderzoek Bij Primair Levercarcinoom" (). In 1941, with the final publication of the GTNI, there were two writings of Leimen about "Over Lecaemieen bij Kinderen" and "Een Geval van scrub-Typhus / Tropical Typhus.

The majority of the diseases he studied before independence were related to the diseases of the poor, particularly those concerning nutrition. Consequently, when Leimena took office, the direction of his policies corresponded with what he had written and researched. Leimena implemented his ideas when he became Minister of Health with integrated health development in rural areas. Leimena saw a relationship between disease and poverty, the sick became poor, and poverty gave birth to an even more chronic diseases. For Leimene, what needed to be improved was the social conditions of the people for the development of health standards (Johannes Leimena, 1956: 9). Leimena also saw the relationship between people's health and health workers. In his writing "Indonesian People's Health, Views and Planning” Leimena stated that whatever health efforts were undertaken would not be complete without sufficient medical personnel such as doctors, nurses and midwives (Johannes Leimena, 1955: 15). His efforts were in line with his friend Bahder Djohan's responsibilities as PPK Minister. Leimena's aspirations and efforts in carrying out tasks were pursued and focused in a 
program known as the Bandung Plan. The Bandung Plan was a blueprint for Indonesia's health policy that has been initiated and implemented since Leimena became Minister of Health in 1951 (Vivek Leelakantan, 2019). This effort received a good response from various parties who praised him: "Whoever the prime minister is, Leimena remains the Minister of Health." Leimena was re-appointed the Minister of Health in successive governments because of his efforts which won the trust of the Indonesian people.

\section{Conclusion}

Being a doctor did not automatically grant bumiputra doctors ready access to medical publications or the ability to add information to scientific understanding. The government was racist and discriminatory, as evidenced by the stark difference between the salaries of bumiputra doctors and European doctors. GTNI, the medical journal of the Netherlands Indies which contained a variety of tropical health information, was not made available for most native doctors. The restricted availability of GTNI, as a media for internal reports of health officials made the Dutch East Indies government, meant knowledge was not shared with native doctors. The reason given that native doctors did not meet the professional standards of a (European) doctor was merely an excuse to argue against providing reading access to bumiputra doctors.

On the other hand, bumiputra doctors were provided with specialist journal by Stovia, namely the TVIG journal. The work of bumiputra doctors published in TVIG illustrates their ability as doctors as well as scientists. Their writing was highly praised and beneficial to the Dutch East Indies government. The quality of the work of indigenous doctors led TVIG to be seen as a partner journal and a rival to GTNI. The important subjects they researched and discussed in TVIG were not available to European doctors. European teachers and doctors also used the ability of bumiputra doctors to access local health information by making them information collectors. However, when TVIG came fully under the control of native doctors in 1920, the Dutch East Indies government stopped funding TVIG publications.

The discrimination that increasingly limited bumiputra doctors access to medical knowledge was voiced passionately in Orgaan - the VIG's medium. Likewise, this advocacy was brought to the Volksraad table and written in the newspaper so that some of demands could not be rejected, especially the ability to obtain GTNI access rights. The limited access rights of GTNI was an important factor in why few native doctors could contribute to it.. The elite native doctors who actively wrote for GTNI reflected on their work during Indonesia's independence, including Bahder Djohan and Johannes Leimena. They were like two sides of a coin that complemented each other to build science and public health policy in the newly independent Indonesia. Their 
efforts and work during the Dutch East Indies era were drawn upon they were given responsibilities as Minister of PPK and Minister of Health inIndonesia.

\section{References}

\section{Archives of Official Publications}

Burg, C.L.Van Der (1893). Tijdschrift voor Inlandsche Geneeskundigen. Eerste Jaargang. Batavia: Landsdrukkerij.

Djoko Marihandono (Editor\& Penterjemah) (1906). Laporan Tahunan Sekolah Pendidikan Dokter Bumiputra di Weltevreden tahun ajaran 1905. Jakarta: Museum Kebangkitan Nasional.

Djoko Marihandono (Editor\& Penterjemah) (1994). Laporan Tahunan Sekolah Pendidikan Dokter Bumiputra di Weltevreden tahun ajaran 1902-1903. Jakarta: Museum Kebangkitan Nasional.

Feuilleton (1928). In memoriam Dr. Lim Njat Fa en zijn verdienste voor de ontwikkeling van het ziekenhuis- en verpleegwezen op Java, in NTVG 72.I.II: 1346

Langen, C.D.de (1915). Aan de Lezers. Tijdschrift voor Inlandsche Geneeskundigen (TVIG): 23/1: 1-4.

Langen, C. D. De \& Bahder Djohan (1935). Pellagra in Nederlandsch-Indië. Geneeskundig Tijdschrift voor Nederlandsch-Indië (GTNI), 75/8: 659-662.

Mardanas Safwan (1985). Prof. Dr. Bahder Djohan, Karya Dan Pengabdiannya. Jakarta: Departemen Pendidikan Dan Kebudayaan Direktorat Sejarah Dan Nilai Tradisional.

Seno,R (1919). Ons Tijdschrif. Tijdschrift voor Inlandsche Geneeskundigen (TVIG) 27, mo 2 (1919), 1-6.

Tobing, F.L (1925). Medisch Dispuut Gezelschap. in STOVIA almanak 1925. Weltevreden: Kolff,

\section{Books, Journals, Dissertations}

A.A. Laodin (2005). Sejarah Kedokteran di Bumi Indonesia. Jakarta: Pustaka Utama Grafiti.

Bahder Djohan (1980). Sekolah ke Betawi, in Bahder Djohan Pengabdi Kemanusiaan. Jakarta: PT Gunung Agung.

Bahder Djohan (1980). Menjadi Dokter, dalam; Bahder Djohan Pengabdi Kemanusiaan. Jakarta: PT Gunung Agung.

Bahder Djohan (1980), De Positie Van de Vrouw in de Indonesische Samenleving, verslag van het Eerste Indoneische Jengdevingres, Terjemahan Darsjaf Rahman. Jakarta: Yayasan ldayu.

Darsyaf Rahman (1980). Bahder Djohan Pribadi yang menarik, dalam Bahder Djohan Pengabdi Kemanusiaan. Jakarta: PT Gunung Agung.

Dieka Wahyudha Mardheni (2017). Gaya Hidup Modern Siswa Kedokteran (Elève) di Batavia, 1851 - 1927. (Thesis, Universitas Gadjah Mada, Yogyakarta).

Gani Jaelani (2019). Naturalis, Dokter, dan Ahli Ilmu Bumi: Penyelidikan Gempa dan Gunung Meletus di Hindia-Belanda pada Abad ke-19. Jurnal Sejarah 2/ 2: $32-49$

Graves, Elizabeth E. (1981). The Minangkabau Response to Dutch Colonial Rule in the Nineteenth Century. Ithaca: Cornell Modern Indonesia Project.

Hasselink, Liesbeth (2019). Para Penulis Hindia, dalam Leo van Bergen, Liasbeth 
Hasselink, Jan Peter Perhave (Ed.) Gelanggang Riset Kedokteran di Bumi Indonesia. Jakarta: AIPI.

Hesselink, Liesbeth, Jan Peter Verhave, \& Leo van Bergen (Eds) (2019). The Medical Journal of the Dutch Indies 1852-1942. A Platform for Medical Research. Jakarta: AIPI.

Hornig, P. \& F. Verdoorn (1945). Sciences and Scientists in the Netherlands Indies. N.Y: Board for the Netherlands Indies, Surinam and Curacao.

Johannes Leimena (1953). Some aspects of health protection to local areas in Indonesia. Jakarta: Ministry of Health, Indonesia.

Johannes Leimena (1956). Public Health in Indonesia. Problems and Planning. Jakarta: Van Dorp \& Co.

Johannes Leimena (1955). Kesehatan Rakjat di Indonesia, Pandangan dan Planning. Djakarta, Bandung, Semarang, Surabaya: G.C.T Van Dorp \& Co.

M.Natsir (1980). Pemimpin Perintis: Bahder Djohan, dalam Bahder Djohan Pengabdi Kemanusiaan. Jakarta: PT Gunung Agung.

Neelakantan, Vivek (2019). Memelihara Jiwa Raga Bangsa, Ilmu Pengetahuan, Kesehatan Masyarakat dan Pembangunan Indonesia di Era Soekarno. Jakarta: Penerbit Kompas.

Nugroho Notosusanto (editor) (1977). Sejarah Nasional Indonesia IV. Jakarta: Balai Pustaka.

Pols, Hans (2019). Merawat Bangsa, Sejarah Pergerakan Para Dokter Indonesia. Jakarta: Penerbit Kompas.

Pols, Hans. Kisah Dokter-Dokter Kebanggaan Indonesia Pada Masa Penjajahan Belanda, dalam https://nationalgeographic.grid.id. Selasa, 21 November 2017

Thalib Ibrahim (1975). Jiwa Juang Bangsa Indonesia. Jakarta: Mahabudi.

Victer Silean (Editor) (2007). Dr. Johannes Leimena, Negarawan Sejati \& Politisi Berhati Nurani. Jakarta: PT BPK Gunung Mulia.

Waart, A. de Tujuh Puluh Lima Tahun Pendidikan Kedokteran di Weltevreden 1851-1926. 